\title{
GIMDOS KŪNO IR KAKLELIO VËŽIO PACIENČIŲ, GYDYTŲ SUDERINTA FOTONŲ IR NEUTRONŲ RADIOTERAPIJA NUO VIETIŠKAI IŠPLITUSIO VËŽIO, ILGALAIKIO STEBËJIMO REZULTATAI
}

\author{
Vitalija Samerdokienė, Konstantinas Povilas Valuckas, Ernestas Janulionis, \\ Vydmantas Atkočius \\ Nacionalinis vežio institutas
}

Raktažodžiai: antrieji pirminiai piktybiniai navikai, spindulinè terapija, gimdos kūno ir kaklelio vėžys, ilgalaikis išgyvenamumas.

\section{Santrauka}

Jonizuojančioji spinduliuotè, naudojama piktybiniu naviku gydymui, laikui bėgant gali sukelti antruosius pirminius piktybinius navikus (APPN). Tyrimo metu buvo vertinamas APPN paplitimas tarp 1143 spinduline terapija (ST) 1989-1999 metu laikotarpiu gydytų IIB ir IIIB stadijos gimdos kaklelio ir I-III stadijos gimdos kūno vèžiu sergančių pacienčių. Viena grupé pacienčių $(\mathrm{N}=538)$ buvo gydyta distancine ${ }^{60} \mathrm{Co}$ gama terapija ir didelès dozès galios (DDG) fotonu ${ }^{60} \mathrm{Co}$ brachiterapija, o kita grupé $(\mathrm{N}=605)$ - distancine ${ }^{60} \mathrm{Co}$ gama terapija ir DDG neutronų ${ }^{252} \mathrm{Cf}$ brachiterapija.

Yra pakankamai literatūros duomenų, rodančių APPN dažni, nustatytą po distancinès ${ }^{60} \mathrm{Co}$ gama terapijos taikymo, APPN lokalizacijas ir organo apšvitos dozę. Apie APPN dažnị, nustatytą po neutronų ${ }^{252} \mathrm{Cf}$ brachiterapijos, gydant gimdos kūno ir kaklelio vietiškai išplitusi vėžĭ, literatūros nebuvo rasta. Mūsų tyrimas 25 metus stebint onkologines pacientes, gavusias DDG fotonu ${ }^{60} \mathrm{Co}$ arba neutronų ${ }^{252} \mathrm{Cf}$ brachiterapiją, parodè, kad tarp visų stebètų 1143 pacienčių buvo diagnozuoti 83 (7,26 proc.) APPN atvejai. 46 (4,02 proc.) APPN atvejai nustatyti pacienčių, gavusių neutronų ${ }^{252} \mathrm{Cf}$ brachiterapiją ir 37 atvejai (3,24 proc.) - gavusių fotonų ${ }^{60} \mathrm{Co}$ brachiterapija (nèra statistiškai reikšmingo skirtumo: $p=0,554)$. APPN dažniai tarp Lietuvos pacienčių, gavusių neutronų ${ }^{252} \mathrm{Cf}$ brachiterapiją ir gavusių fotonų ${ }^{60} \mathrm{Co}$ brachiterapiją, nesiskyrè nuo kitų šalių tyrëjų publikacijose pateiktų APPN dažnių. Vietiš- kai išplitusio vėžio pacienčiu išgyvenamumas II B stadijos pacientems buvo toks pat abiejose (fotonų ${ }^{60} \mathrm{Co}$, ir neutronu ${ }^{252} \mathrm{Cf}$ ) brachiterapijos grupèse $(\mathrm{p}=0,737)$. III B stadijos pacientems nustatytas statistiškai reikšmingai geresnis išgyvenamumas neutronų ${ }^{252} \mathrm{Cf}$ brachiterapijos grupeje (skirtumas $10-12$ proc.: $\mathrm{p}=0,004)$. Didžiausi APPN dažniai buvo stebèti tarp didelę ir mažą apšvitos dozę gavusių kūno anatominių sričių. Vidutinę apšvitos dozę gavusiose srityse APPN buvo stebèti rečiausiai. Neutronų ${ }^{252} \mathrm{Cf}$ brachiterapija gydytoms pacientems buvo rasta statistiškai reikšmingai mažiau navikų recidyvų.

Remiantis gautais rezultatais išspausdinti trys straipsniai aukšto reitingo tarptautiniuose (ISI) žurnaluose (du-Q1 ir vienas Q2 lygio).

\section{Ivadas}

Gimdos kūno ir kaklelio vėžys - vienas iš labiausiai paplitusių pasaulyje moterų vėžio lokalizacijų [1]. Spindulinè terapija (ST) šiandieniniame pasaulyje yra vienas iš efektyviausių vėžio gydymo būdų. Jis taikomas maždaug 40-60 proc. onkologinių pacientų. Ypač efektyviai spindulinis gydymas taikomas prieš vietiškai išplitusị (gimdos kaklelio II B ir III B stadija) vėži ir pooperacinejje praktikoje po gimdos kūno ekstirpacijos, švitinant ị naviko guolị ir regioninius limfmazgius (gimdos kūno I-III stadija).

Didejantis sergamumas antraisiais pirminiais piktybiniais navikais (APPN) tarp onkologinių pacienčių, gydytų spinduline terapija (ST) nuo pirminiu piktybinių naviku (PPN), kelia medicinos personalui vis didesnị susirūpinimą. Neabejotina, kad šiam reiškiniui įtakos turi pasiektas ženklus ilgalaikis išgyvenamumas po PPN gydymo. Tai medicinos progreso, taikant naujas gydymo technologijas, padarinys. Pacienčių su trumpesniu ( $<10$ metų) išgyvenamumu grupeje APPN yra palyginti retas reiškinys, tačiau 
15 metų ir daugiau išgyvenusių moterų grupèje APPN dažnis ženkliai padidejja [2-5]. Didelis dèmesys šiuo metu skiriamas radiogeninès kilmès APPN, jų paplitimo, sergamumo ir mirtingumo nuo šių navikų bei etiopatogenezès tyrimams, nes per pastaruosius metus visiškai pasikeitė ST technologijos.

Norvegų, suomių, švedų, danų ir JAV jungtinio tyrimo bei japonų mokslininkų grupès duomenimis [6,7], didžiausia APPN rizika yra tiems dubens srities organams, kurie yra greta gimdos kūno ir kaklelio ir gauna dideles spinduliuotès dozes $(>3,0$ Gy): makštis, tiesioji žarna, šlapimo pūslè ir kiaušidès. Tokie APPN po spindulinès terapijos taikymo PPN gydyti suteikia mokslui svarbios informacijos apie spindulinès kilmès vėži. Kadangi dauguma pacienčių, gydytų ST nuo gimdos kūno ir kaklelio vėžio, ilgai išgyvena po joms taikyto PPN gydymo, šis modelis puikiai tinka vėlyvujų stochastinių efektų, tarp jų ir antrujų pirminių piktybinių navikų, savalaikiam nustatymui ir detalesnems APPN studijoms [8-10].

Praeito šimtmečio 9-ajame dešimtmetyje prof. Y. Maruyama iniciatyva JAV pradèta taikyti neutronu ${ }^{252} \mathrm{Cf}$ brachiterapija gimdos kaklelio vėžiui gydyti $[11,12]$. Ji ypač pasiteisino, tikintis efektyvesnių gydymo rezultatų vietiškai išplitusio gimdos kaklelio věžio atvejais [13]. Tyrimus šioje srityje tęsė T.Tačev [14], taikydamas mažos dozės galios (MDG) ${ }^{252} \mathrm{Cf}$ šaltinius bei L.A.Marjina [15], dirbusi su didelès dozès galios (DDG) ${ }^{252} \mathrm{Cf}$ šaltiniais.

Nacionaliniame véžio institute (NVI) buvo inicijuotas ir sẻkmingai igyvendintas didelès apimties, šiuolaikinèmis metodikomis pagrisstas LMT Mokslininkų grupių projektas (MIP-036/2013) „Antrieji pirminiai piktybiniai navikai tarp spinduline terapija gydytų onkologinių pacienčių“ (projekto vadovas prof. habil. dr. K.P. Valuckas). Šiuo projektu buvo siekiama pirmą kartą pasaulyje nustatyti 1989-1999 metų laikotarpiu diagnozuotu NVI gimdos kūno ir kaklelio vėžio pacienčių, kurių gydymui buvo taikyta suderinta ST (t.y. gama terapija ir dviejų rūšių brachiterapija), išgyvenimo trukmę, atokius klinikinius reiškinius ir antrujų pirminių piktybinių navikų šių pacienčių populiacijoje atsiradimo dažnius.

Darbo tikslas - ištirti antrujų pirminių piktybinių navikų riziką pacientems, gydytoms suderinta spinduline terapija nuo gimdos kūno ir kaklelio vèžio, taikant dviejų rūšių (neutronų ${ }^{252} \mathrm{Cf}$ ir fotonų ${ }^{60} \mathrm{Co}$ ) brachiterapijas ir ịvertinti atokius šio gydymo rezultatus.

\section{Tyrimo metodika}

Kohorta buvo sudaryta iš moterų, kurioms buvo diagnozuotas pirminis gimdos kūno (TLK-
10: C54, C55) ir gimdos kaklelio (TLK-10: C53) vėžys ir kurios išgyveno mažiausiai du mènesius po pirminio gimdos kaklelio vėžio diagnozès ir buvo registruotos NVI Hospitaliniame registre. Visi vėžio atvejai buvo sukoduoti Tarptautinès ligų klasifikacijos, 10 versijos (TLK-10) kodais [16].

APPN identifikacijai taikyti šie įtraukimo ị tyrimą kriterijai: pacientès, gavusios suderintą ST pirminio vietiškai išplitusio gimdos kaklelio vėžio gydymui; pacientès, gavusios suderintą ST pooperacinèje praktikoje po gimdos kūno ekstirpacijos, švitinant ị naviko guolị ir regioninius limfmazgius (gimdos kūno I-III stadija); 2 metų laikotarpis nuo pirmojo pirminio naviko ST pradžios iki antrojo pirminio piktybinio naviko diagnozès. Neįtraukimo ị tyrimą kriterijai: pacientès, kurioms buvo diagnozuoti APPN, nepraejjus 2 metams po pirminio gimdos véžio diagnozès; chemoterapija gydytos pacientės; operuotos neišplitusio véžio pacientès. Visoms tyrime dalyvavusioms ginekologinèms pacientèms $(\mathrm{N}=1143)$ buvo taikyta suderinta spindulinè terapija pagal institute patvirtintą gydymo metodiką, t. y. išorinè gama terapija, naudojant ${ }^{60} \mathrm{Co}$ šaltinį ir ertmine brachiterapija, naudojant vieną iš dviejų spinduliuotès šaltinių: ${ }^{252} \mathrm{Cf}(\mathrm{N}=605)$ arba ${ }^{60} \mathrm{Co}(\mathrm{N}=538)$.

\section{Rezultatai ir jų aptarimas}

Tyrimo metu buvo nustatyta, kad tarp visų 1143 Lietuvos gimdos kūno ir kaklelio véžiu sirgusių pacienčių, gydytų suderinta ST, per visą tolesni jų 25 metu stebėjimo laikotarpi buvo diagnozuoti 83 (7,3 proc.) APPN. APPN pasiskirstymas pagal pacienčių gydymui taikytą brachiterapijos rūši buvo toks: pacienčių, gavusių neutronų ${ }^{252} \mathrm{Cf}$ ir fotonų ${ }^{60} \mathrm{Co}$ apšvitą, buvo 46 (7,6 proc.) ir 37 (6,9 proc.), atitinkamai.

Analizuojant kumuliacinị APPN dažnị (1 pav.) po 5, 10, 15, 20 ir 25 stebejjimo metų nuo pirminio gimdos kūno ir kaklelio véžio diagnozès, neutronų ${ }^{252} \mathrm{Cf}$ ir fotonų ${ }^{60} \mathrm{Co}$ brachiterapijos rūšis gavusioms ginekologinèms pacientèms, statistiškai reikšmingo skirtumo negavome $(\mathrm{p}=0,769)$.

Analizuojant APPN dažni pagal pacienčių gydymui

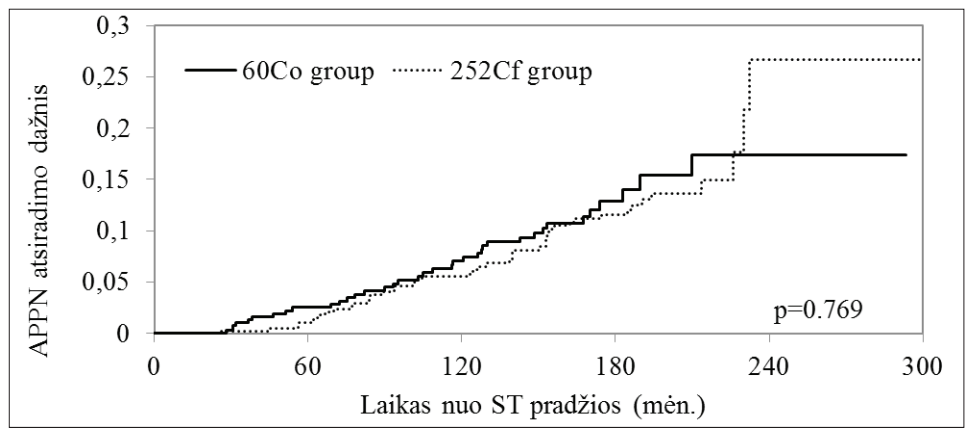

1 pav. Gimdos kūno ir kaklelio vėžio pacienčių kumuliacinis antrųų pirminių piktybinių navikų išsivystymo dažnis 25 metų stebejjimo laikotarpiu 
1 lentelè. Antrųjų pirminių piktybinių navikų (APPN) dažnis pacientėms, gydytoms neutronų ${ }^{252 \mathrm{Cf}}$ ir fotonų ${ }^{60} \mathrm{Co}$ brachiterapija (BT), 25 metų stebèjimo laikotarpiu

\begin{tabular}{|c|c|c|c|c|}
\hline $\begin{array}{l}\text { Apšvitinimo } \\
\text { laipsnis [6] }\end{array}$ & $\begin{array}{c}\text { Vidutinè } \\
\text { organo } \\
\text { dozė (Gy) }\end{array}$ & $\begin{array}{c}\text { Neutronuc } \\
{ }^{252} \mathrm{Cf} \text { BT } \\
\mathrm{N}=605\end{array}$ & $\begin{array}{c}\text { Fotonuy } \\
{ }^{60} \mathrm{Co} \text { BT } \\
\mathrm{N}=538\end{array}$ & Iš viso \\
\hline Stipriai apšvitinta & $>3,0$ & 17 & 14 & $\begin{array}{c}31 \\
(37,4 \%) \\
\end{array}$ \\
\hline Vidutiniškai apšvitinta & $1,0-3,0$ & 5 & 3 & $8(9,6 \%)$ \\
\hline Silpnai apšvitinta & $<1,0$ & 21 & 16 & $\begin{array}{c}37 \\
(44,6 \%) \\
\end{array}$ \\
\hline Hematologinè terpè & & 3 & 4 & $7(8,4 \%)$ \\
\hline Iš viso & & 46 & 37 & $\begin{array}{c}83 \\
(100,0 \%)\end{array}$ \\
\hline
\end{tabular}

2 lentelè. APPN dažnis pagal pacienčių amžiaus grupes (riba - amžiaus mediana, metais) 25 metų stebèjimo laikotarpiu

\begin{tabular}{|l|c|c|c|c|}
\hline Amžius diagnozės metu, m & Pacientės & APPN & $\mathbf{\%}$ & P-reikšmè \\
\hline Neutronų ${ }^{252} \mathrm{Cf} \mathrm{BT}<57,43$ & 302 & 17 & 5,63 & 0,823 \\
\hline Fotonų ${ }^{60} \mathrm{Co}$ BT $<57,44$ & 269 & 14 & 5,20 & \\
\hline Neutronų ${ }^{252} \mathrm{Cf}$ BT $\geq 57,45$ & 303 & 29 & 9,57 & 0,672 \\
\hline Fotonų ${ }^{60}$ Co BT Co $\geq 57,46$ & 269 & 23 & 8,55 & \\
\hline Iš viso $<57,44$ & 571 & 31 & 100,00 & $\mathbf{0 , 0 1 7}$ \\
\hline Iš viso $\geq 57,45$ & 572 & 52 & 100,00 & \\
\hline
\end{tabular}

naudotą brachiterapijos rūši ir skirtingą gretimų organų apšvitinimo dozę, sekant Kleinerman R. ir kt. [6] autorių patirtimi, buvo nustatyta, kad ginekologinio vèžio $(\mathrm{N}=605)$ pacienčių, kurioms buvo taikyta neutronų ${ }^{252} \mathrm{Cf}$ brachiterapija, grupeje per 25 metų laikotarpi išsivyste 46 APPN. 17 iš jų buvo diagnozuota didelę, 5 - vidutinišką, 21 - mažą apšvitą patyrusiose organizmo srityse ir 3 APPN - hematologinèje terpejje. Ginekologinio vėžio pacienčių $(\mathrm{N}=538)$, kurioms buvo taikyta fotonu ${ }^{60} \mathrm{Co}$ brachiterapija, grupèje per 25 metų laikotarpi išsivyste 37 APPN. 14 iš jų diagnozuoti didelès, 3 - vidutiniškos, 16 - mažos apšvitos organizmo srityse ir 4 APPN - hematologinejje terpeje (1 lentelè).

Nors APPN dažnis tarp neutronų ${ }^{252} \mathrm{Cf} \mathrm{BT}$ ir fotonu ${ }^{60} \mathrm{Co}$ brachiterapija gydytų jaunų $(<57,43 \mathrm{~m})$ ir vyresnių $(\geq 57,70$ m) pacienčių buvo panašus, tačiau vyresnio amžiaus visų tyrime dalyvavusių pacienčių grupeje ( $\geq 57,43$ metų) buvo diagnozuota statistiškai reikšmingai daugiau $(p<0,017)$ antrųjų pirminių vėžio atvejų (2 lentelè).

Gimdos kaklelio véžio pacienčių duomenis analizuojant pagal vietiškai išplitusio vėžio stadijas, gauta, kad metastazavimo dažnis abiejose II B vėžio stadijos pacienčių, gavusių skirtingą brachiterapijos rūšį, grupèse buvo vienodas (2 pav.). Tuo tarpu lokalūs vėžio recidyvai buvo statistiškai reikšmingai retesni tarp pacienčių, gydytų neutronų ${ }^{252} \mathrm{Cf}$ brachiterapija $(\mathrm{p}=0,024)$ (3 lentelè).

Gimdos kaklelio vėžio pacienčių, sirgusių III B stadijos vèžiu, gydymo rezultatai parodè, kad pacienčių, gydytų neutronų ${ }^{252} \mathrm{Cf}$ brachiterapija, grupèje ilgalaikis $(5,10,15$ metų) išgyvenamumas buvo $10-12$ proc. geresnis $(\mathrm{p}=0,004)$, palyginti su pacientemis, gydytomis standartine fotonų spinduline terapija (3 pav.). Vèlyvujų komplikacijų dažniai abiejose neutronų ${ }^{252} \mathrm{Cf}$ ir fotonų ${ }^{60} \mathrm{Co}$ brachiterapiją gavusių pacienčių grupèse nesiskyrè. Išimtis - hidronefrozès. Hidronefrozių rasta statistiškai reikšmingai gausiau tarp rutininę fotonų ${ }^{60} \mathrm{Co}$ brachiterapiją gavusių pacienčių $(\mathrm{p}=0,039)$.

Tyrimo metu buvo nustatyti šie pagrindiniai rizikos veiksniai, statistiškai reikšmingai turintys itakos pacienčių išgyvenimo prognozei. Neutronų ${ }^{252} \mathrm{Cf}$ brachiterapija gydytu pacienčiu grupèje - histologinis APPN tipas (plokščialąstelinè karcinoma), o rutininę fotonų ${ }^{60} \mathrm{Co}$ brachiterapiją gavusių pacienčiu grupejje - ir histologinis APPN tipas, ir věžio recidyvas.

APPN, recidyvų ir metastazių dažniai abiejose vėžio gydymui taikytos brachiterapijos rūšies pacienčiu grupèse buvo panašūs. Tikètina, kad neutronų ${ }^{252} \mathrm{Cf}$ brachiterapijos radiogeninès ir kancerogeninès pasekmès yra adekvačios toms pasekmèms, kurios atsiranda po spindulinio gydymo fotonais.

Ilgalaikis 1143 ginekologinio véžio pacienčių stebèjimas leido ịvertinti APPN atsiradimo dažnius po šiu pacienčių gautos neutronų ${ }^{252} \mathrm{Cf}$ apšvitos ir palyginti su pacienčiu grupe, gydytų fotonų ${ }^{60} \mathrm{Co}$ brachiterapija. Tyrimo

$$
1.0-\longdiv { k }
$$

Išgyvenamumas, proc.

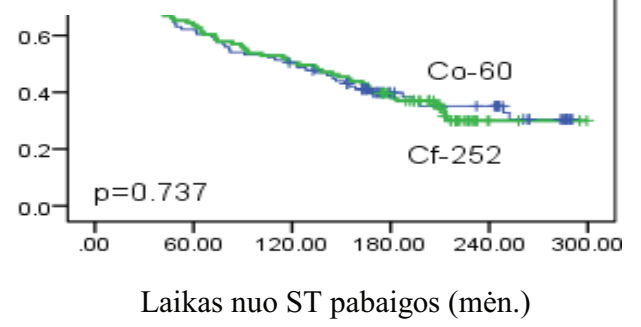

2 pav. II B pacienčių išgyvenamumas priklausomai nuo brachiterapijos rūšies $\left({ }^{252} \mathrm{Cf}\right.$ vs. $\left.{ }^{60} \mathrm{Co}\right)$ 
3 lentelè. Recidyvų ir metastazių paplitimo dažniai tarp skirtingą brachiterapijos rūšị gavusių II B stadijos gimdos kaklelio vėžio pacienčių per 25 metų laikotarpi

\begin{tabular}{|l|c|c|c|c|c|}
\hline $\begin{array}{l}\text { Atokūs } \\
\text { reiškiniai }\end{array}$ & \multicolumn{2}{|c|}{$\begin{array}{c}\text { Neutronų } \\
{ }^{252} \text { Cf B B }\end{array}$} & \multicolumn{2}{|c|}{$\begin{array}{c}\text { Fotonų } \\
{ }^{60} \text { Co BT }\end{array}$} & $\begin{array}{c}\text { p-reikš- } \\
\text { mé }\end{array}$ \\
\hline & $\mathrm{N}$ & proc. & $\mathrm{N}$ & proc. & \\
\hline Recidyvai & & & & & \\
\hline Taip & 9 & 7,44 & 19 & 17,12 & $\mathbf{0 , 0 2 4}$ \\
\hline Ne & 112 & 92,56 & 92 & 82,88 & \\
\hline Metastazės & & & & & \\
\hline Taip & 10 & 8,26 & 14 & 12,61 & 0,277 \\
\hline Ne & 111 & 91,74 & 97 & 87,39 & \\
\hline
\end{tabular}

metu buvo gauta, kad lokali didelès dozès galios neutronų apšvita nesukèlè didesnio APPN skaičiaus, palyginti su fotoninès apšvitos pacienčių grupe $(\mathrm{p}=0,769)$.

Lyginant su kitų šalių vėžio pacientėms taikyta suderintos ST praktika, mūsų tyrimo metu tirtų Lietuvos gimdos kaklelio véžio pacienčių, gydytų neutronų ${ }^{252} \mathrm{Cf}$ brachiterapija, išgyvenamumas buvo panašus ị kitose šalyse gautus rezultatus [17-19]. Dar daugiau - mūsų tyrimo pacienčių grupe buvo homogeniška (analizuotos tik IIB-III B stadijos pacientés), o kitose šalyse buvo tiriamos visų stadijų pacientès (mišri, nehomogeniška grupè).

\section{Išvados}

1. Per 25 metų laikotarpi tarp 605 pacienčių, gydytų neutronų ${ }^{252} \mathrm{Cf}$ brachiterapija ir 538 pacienčių, gydytų fotonų ${ }^{60}$ Cobrachiterapija, stebèti46ir37APPNatvejai, atitinkamai.

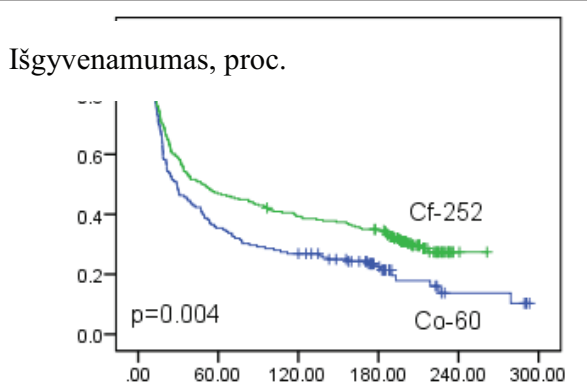

Išgyvenamumas, proc.

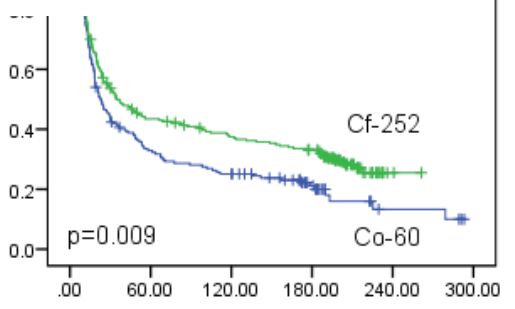

Laikas nuo ST pabaigos (mèn.)

\begin{tabular}{|c|c|c|c|c|c|c|c|c|c|}
\hline \multicolumn{5}{|c|}{ OS - bendras išgyvenamumas } & \multicolumn{5}{|c|}{ DFS - išgyvenamumas be ligos } \\
\hline & $5 \mathrm{~m}$. & $10 \mathrm{~m}$. & $15 \mathrm{~m}$. & p-reikšmè & & $5 \mathrm{~m}$. & $10 \mathrm{~m}$. & $15 \mathrm{~m}$. & $\begin{array}{l}\text { p-reikš- } \\
\text { mé }\end{array}$ \\
\hline${ }^{252} \mathrm{Cf}$ & 46,9 & 39,3 & 34,6 & \multirow{2}{*}{0,004} & ${ }^{252} \mathrm{Cf}$ & 43,4 & 37,5 & 33,2 & \multirow{2}{*}{0,009} \\
\hline${ }^{60} \mathrm{Co}$ & 35,4 & 26,9 & 22,5 & & ${ }^{60} \mathrm{Co}$ & 32,9 & 25,1 & 21,1 & \\
\hline
\end{tabular}

3 pav. III B pacienčių išgyvenamumas priklausomai nuo vėžio gydymui taikytos brachiterapijos rūšies $\left({ }^{252} \mathrm{Cf}\right.$ vs. $\left.{ }^{60} \mathrm{Co}\right)$
2. APPN dažnis buvo panašus tarp vėžio pacienčių, gavusių neutronų ${ }^{252} \mathrm{Cf}$ brachiterapiją, palyginti su pacientėmis, gavusiomis fotonų ${ }^{60} \mathrm{Co}$ brachiterapiją, ir nesiskyrè nuo kitų šalių tyrejuu publikacijose pateikto APPN dažnio.

3. Didžiausi APPN dažniai nustatyti tarp didelę ir mažą apšvitos dozę gavusių švitinamo organizmo organų, o vidutinę apšvitos dozę gavusiuose organuose APPN buvo stebèti rečiausiai.

4. II B stadijos gimdos kaklelio vėžio pacienčiu išgyvenamumas buvo vienodas abiejose (fotonų ${ }^{60} \mathrm{Co}$ ir neutro$n u{ }^{252} \mathrm{Cf}$ ) brachiterapijos grupèse.

5. III B stadijos gimdos kaklelio véžio pacienčiu išgyvenamumas neutronų ${ }^{252} \mathrm{Cf}$ brachiterapijos grupejje buvo $10-14$ proc. didesnis palyginti su fotonų ${ }^{60} \mathrm{Co}$ brachiterapiją gavusių pacienčių grupe $(\mathrm{p}=0,004)$.

6. Išsamūs tyrimo rezultatai ir jų aptarimas paskelbtas 3-juose tarptautiniuose mokslo žurnaluose [20-22].

\section{Padèka}

Projektą rèmé Lietuvos mokslo taryba (sutarties Nr. MIP-036/2013).

\section{Literatūra}

1. Globocan 2012. Available at: http://globocan.iarc.fr/Pages/ fact_sheets_population.aspx.

2. Suit H, Goldberg S, Niemierko A, Ancukiewicz M, Hall E, Goitein M, Wong W, Paganetti H. Secondary carcinogenesis in patients treated with radiation: a review of data on radiationinduced cancers in human, non-human primate, canine and rodent subjects. Radiat Res. 2007; 167(1):12-42.

http://dx.doi.org/10.1667/RR0527.1

3. Trott KR. Second cancers after radiotherapy. In: Vand der Kogel Jr. Basic clinical radiobiology. London: Hodder publ 2008.

4. Tubiana M. Radiobiologie. Herman/Medicine: Paris 2008.

5. Hall EJ, Giaccia A. Radiobiology for the radiologist. Lippincott, Williams and Wilkins. 2006.

6. Kleinerman RA, Boice JD, Jr Storm HH, Sparen P, Andersen A, Pukkala E, Lynch CF, Hankey BF, Flannery JT. Second primary cancer after treatment for cervical cancer. Cancer. 1995; 76(3):442-52.

http://dx.doi.org/10.1002/10970142(19950801)76:3<442:: CNCR2820760315>3.0.CO;2-L

7. Ota T, Takeshima N, Tabata $\mathrm{T}$, Hasumi K, Takizawa K. 
Treatment of squamous cell carcinoma of the uterine cervix with radiation therapy alone: long-term survival, late complications, and incidence of second cancers. Br J Cancer 2007; 97(8):1058-62.

http://dx.doi.org/10.1038/sj.bjc.6604005

8. Arnold M, Liu L, Kenter GG, Creutzberg CL, Coeberg JW, Soerjomataram I. Radiotherapy and oncology. 2014; 111(3):374-381. Available at: http://dx.doi.org/10.1016/j. radonc.2014.04.011.

http://dx.doi.org/10.1016/j.radonc.2014.04.011

9. Chaturvedi AK, Engels EA, Gilbert ES, Chen BE, Storm H, Lynch CF, Hall P, Langmark F, Pukkala E, Kaijser M, Anderson M, Fossa SD, Joensuu H, Boice JD, Kleinermam RA, Travis LB. Second cancers among 104760 survivors of cervical cancer: evaluation of long-term risk. JNCI 2007; 99(21):1634-42. http://dx.doi.org/10.1093/jnci/djm201

10. Ohno T, Kato S, Sato S, Fukuhisa K, Nakano T, Tsuji H, Arai $\mathrm{T}$. Long-term survival and risk of second cancers after radiotherapy for cervical cancer. Int J Radiat Oncol Biol Phys 2007; 69(3):740-5. http://dx.doi.org/10.1016/j.ijrobp.2007.04.028

11. Maruyama Y, van Nagell J, Yoneda J. et al. A review of californium-252 neutron brachytherapy for cervical cancer. Cancer 1991; 68:1189e1197.

12. Maruyama Y, Feola JM, Beach J. HeLa cell tumor response to $60 \mathrm{Co}, 137 \mathrm{Cs}, 252 \mathrm{Cf}$ radiations and cisplatin chemotherapy in nude mice. Cancer 1984; 54:247e252.

13. Maruyama Y, Mesina J, Yudelev M. et al. New understanding from $\mathrm{Cf}$ brachytherapy trails and consideration for neutron brachytherapy f bulky gyn carcinoma for future. Strahlenther Onkol 1994; 50:1123e1135.

14. Tacev T, Ptackova B, Strnad V. Californium-252 versus conventional gamma radiation in the brachytherapy of advanced cervical carcinoma: Long-term treatment results of a randomized study. Strahlenther Onkol 2003; 179:377e384.

15. Marjina LA. High dose rate $252 \mathrm{Cf}$ neutron intraluminal brachytherapy for treatment of cervical carcinoma and corpus carcinoma. Chin J Radiat Oncol 1997; 6:145e146.

16. Valuckas KP, Samerdokienė V, Janulionis E, Atkočius V. Atokūs rezultatai gimdos kaklelio vėžio pacientėms po suderintos spindulinès terapijos. Sveikatos mokslai, 2014; 24(4):111-4. http://dx.doi.org/10.5200/sm-hs.2014.077

17. Zhao H, Wang K, Sun J. et al. Clinical report on external irradiation combined with californium-252 neutron intraluminal brachytherapy for cervical carcinoma treatment. Tumori 2007; 93:636e640.

18. Lei X, Qian CY, Qing Y. et al. Californium-252 brachytherapy combined with external-beam radiotherapy for cervical cancer: Long-term treatment results. Int J Radiat Oncol Biol Phys. 2011; 81:1264e1270.

19. Chen SW, Liang JA, Yang SN. et al. The adverse effect of treatment prolongation in cervical cancer by high-dose-rate intracavitary brachytherapy. Radiother Oncol 2003; 67:69e76.
20. Janulionis E, Valuckas KP, Liukpetryte S, Samerdokiene V, Atkocius V. Californium versus cobalt brachytherapy combined with external-beam radiotherapy for IIB stage cervical cancer: long-term experience of a single institute. Journal of Contemporary Brachytherapy 2015; 7(5):346-51.

http://dx.doi.org/10.5114/jcb.2015.55117

21. Samerdokiene V, Valuckas KP, Janulionis E, Atkocius V, Rivard MJ. Second primary malignancies after radiotherapy including HDR 252Cf brachytherapy for cervical cancer. Brachytherapy 2015; 14:898-904.

http://dx.doi.org/10.1016/j.brachy.2015.06.006

22. Ulinskas K, Janulionis E, Valuckas KP, Samerdokiene V, Atkocius V, Rivard MJ. Long-term results for stage IIIB cervical cancer patients receiving external beam radiotherapy combined with either HDR 252Cf or HDR 60Co intracavitary brachytherapy. Brachytherapy 2016.

http://dx.doi.org/10.1016/j.brachy.2016.02.004

\section{LONG-TERM RESULTS IN CERVICAL AND UTERINE CANCER PATIENTS TREATED WITH COMBINED PHOTON AND NEUTRON RADIOTHERAPY}

V. Samerdokienė, K.P. Valuckas, E. Janulionis, V. Atkočius

Key words: second primary neoplasms, radiotherapy, uterus and cervical cancer, long term results.

Summary

During the long period of time radiation therapy used to cure oncological diseases can cause second primary malignancies (SPM) . In this investigation the spread of SPM was evaluated between 1143 pts treated with radiation therapy (RT) during the period of 1989-1999 with cervix uteri stage II B and III B and corporis uteri stages I-III. One group of pts ( $\mathrm{N}=538$ ) was irradiated with external ${ }^{60} \mathrm{Co}$ gamma therapy and high dose rate (HDR) photon ${ }^{60} \mathrm{Co}$ brachytherapy,another $(\mathrm{N}=605)$ with ${ }^{60} \mathrm{Co}$ external gamma therapy and HDR ${ }^{252} \mathrm{Cf}$ neutron brachytherapy.

There are enough data about frequency of SPM after external ${ }^{60} \mathrm{Co}$ gamma therapy, SPM location and delivery dose. Data about frequency of SPM after neutron ${ }^{252} \mathrm{Cf}$ brachytherapy was not found. Our 25 years follow-up of pts received HDR photon ${ }^{60} \mathrm{Co}$ or neutron ${ }^{252} \mathrm{Cf}$ brachytherapy revieled that in 1143 cases $83(7.26 \%) \mathrm{SPM}$ were diagnosed. $46(4.02 \%)$ of them were treated with neutron ${ }^{252} \mathrm{Cf}$ brachytherapy, $37(3.24 \%)$ with gamma ${ }^{60} \mathrm{Co}$ brachytherapy (where was no significant statistical difference: $\mathrm{p}=0.554$ ). The frequency of SPM in Lithuanian population irradiated with gamma ${ }^{60} \mathrm{Co}$ or neutron ${ }^{252} \mathrm{Cf}$ brachytherapy was similar with the data from other countries. Survival of localy spread II B cancer stage was the same in both brachytherapy groups. Stage III B pts had significant better survival with neutron ${ }^{252} \mathrm{Cf}$ brachytherapy (difference $10-12 \%$ : $\mathrm{p}=0.004$ ). The largest frequences of SPM was noticed in heavy and low irradiated anatomic sites. In medium irradiated doses SPM were rare. Recurrences were found statistically significant less in group treated with ${ }^{252} \mathrm{Cf}$ brachytherapy. Three publications in ISI base journals were published (two-Q-1 and one Q-2 level).

Correspondence to: Vitalija.Samerdokiene@gmail.com

Gauta 2016-04-25 